CLINICAL STUDY

\title{
Aberrant cortisol regulations in bilateral macronodular adrenal hyperplasia: a frequent finding in a prospective study of 32 patients with overt or subclinical Cushing's syndrome
}

\author{
Rossella Libé $^{1,8}$, Joël Coste ${ }^{2,7}$, Laurence Guignat ${ }^{3}$, Frédérique Tissier ${ }^{1,2,4}$, Hervé Lefebvre ${ }^{9}$, Gaëlle Barrande ${ }^{10}$, \\ Christiane Ajzenberg ${ }^{11}$, Igor Tauveron ${ }^{12}$, Eric Clauser ${ }^{2,5}$, Bertrand Dousset ${ }^{2,6}$, Xavier Bertagna ${ }^{1,2,3,8}$, \\ Jérôme Bertherat ${ }^{1,2,3}$ and Lionel Groussin ${ }^{1,2}$ \\ ${ }^{1}$ Department of Endocrinology, Metabolism and Cancer, Institut National de la Santé et de la Recherche Médicale Unité 567, Centre National de la \\ Recherche Scientifique Unité Mixte de Recherche 8104, Institut Cochin, 75014 Paris, France, ${ }^{2}$ Université Paris Descartes, 75006 Paris, France, \\ ${ }^{3}$ Department of Endocrinology, Center for Rare Adrenal Diseases, Assistance Publique des Hôpitaux de Paris, Hôpital Cochin, 75014 Paris, France, \\ ${ }^{4}$ Department of Pathology, Assistance Publique des Hôpitaux de Paris, Hôpital Cochin, 75014 Paris, France, ${ }^{5}$ Service d'Hormonologie, Assistance Publique \\ des Hôpitaux de Paris, Hôpital Cochin, 75014 Paris, France, ${ }^{6}$ Digestive and Endocrine Surgery Unit, Assistance Publique des Hôpitaux de Paris, Hôpital \\ Cochin, 75014 Paris, France, ${ }^{7}$ Biostatistics Unit, Assistance Publique des Hôpitaux de Paris, Hôpital Cochin, 75014 Paris, France, ${ }^{8}$ INCa Comete \\ Network, France, ${ }^{9}$ Department of Endocrinology, University Hospital of Rouen, Institute for Biomedical Research, University of Rouen, 76031 Rouen, \\ France, ${ }^{10}$ Service d'Endocrinologie, CHR d'Orléans, 45032 Orléans, France, ${ }^{11}$ Service de Médecine Interne et Endocrinologie, Hôpital Henri Mondor, \\ 94000 Créteil, France, ${ }^{12}$ Service d'Endocrinologie et Maladies Métaboliques, CHU de Clermont-Ferrand, 63003 Clermont-Ferrand, France
}

(Correspondence should be addressed to L Groussin who is now at Service des Maladies Endocriniennes et Métaboliques, Hôpital Cochin, 27 rue du Faubourg Saint-Jacques, 75014 Paris, France; Email: lionel.groussin@cch.aphp.fr)

\begin{abstract}
Context: ACTH-independent macronodular adrenal hyperplasia (AIMAH) is a rare and heterogeneous condition characterized by abnormal steroid production. Cortisol secretion can be regulated by aberrant hormone receptors.

Objective: A large series of patients with AIMAH were evaluated to provide information on the prevalence and profile of aberrant regulations, in relation with the functional status.

Design and patients: Thirty-two consecutive patients with AIMAH were prospectively studied: 10 had a Cushing's syndrome (CS), and 22 had a subclinical CS (SCS).

Methods: A baseline endocrine evaluation was followed by an in vivo protocol in search of aberrant cortisol responses (seven provocative tests). An acute inhibition test with the somatostatin analog octreotide was also performed.

Results: At least one aberrant cortisol response was identified in 28 of 32 (87\%) patients. The overall prevalence of aberrant responses was independent of the functional status. Responses to the upright posture and to metoclopramide were frequently observed (67 and 56\% respectively). A glucagon response was frequently observed in the SCS group (58\%). A cortisol inhibition by octreotide was specifically found in the three CS patients who positively responded to the mixed meal, and was observed also in 12 of $13(92 \%)$ patients with SCS.

Conclusions: Cortisol responses indicative of aberrant receptor expression were highly prevalent in AIMAH. Thorough phenotyping of AIMAH may help uncover the underlying pathophysiology.
\end{abstract}

European Journal of Endocrinology 163 129-138

\section{Introduction}

ACTH-independent macronodular adrenal hyperplasia (AIMAH) is a rare form of benign bilateral adrenocortical tumor. Nowadays, the most frequent clinical presentation is that of bilateral adrenal incidentalomas. The initial endocrine evaluation usually demonstrates subtle abnormalities of cortisol secretion, most often an abnormal response to the suppression tests, whereas urinary cortisol is still normal, and the clinical features are modest, thereby defining the concept of subclinical Cushing's syndrome (SCS). AIMAH might also be revealed in the diagnostic workup of an overt Cushing's syndrome (CS). AIMAH is a heterogeneous condition, the pathophysiology of which is incompletely understood (1). Without a final histological examination, the diagnosis of AIMAH is based on the clinical phenotype because of the lack of a specific diagnostic marker.

In the last few years, several studies have shown that the steroidogenesis in AIMAH is dependent on nonACTH factors: it is regulated by a variety of non-ACTH circulating factors as the result of aberrant expression of various hormone receptors at the membrane of tumoral adrenocortical cells. Cortisol secretion is therefore 'controlled' by 'ectopic' receptors such as those for glucose-dependent insulinotropic peptide 
(GIP), catecholamine, vasopressin (V2- and V3-vasopressin receptors), serotonin (5-HT7 receptor), and angiotensin II (AT1 receptor) (2-7). The role of 'eutopic' receptors such as those for vasopressin (V1-vasopressin receptor), LH/human chorionic gonadotropin (LH/hCG-R), serotonin (5-HT4 receptor), and leptin is also established (8-11).

Investigative protocols are used in vivo to identify aberrant receptor expression $(12,13)$. The presence of aberrant membrane hormone receptors has been demonstrated in a relatively high proportion of unilateral tumors, and in most patients with AIMAH (1, 13-15). The presence of an abnormal response may help distinguish between various causes of bilateral adrenal hyperplasia. Identification of aberrant receptor may also offer a specific pharmacological approach, or target, to prevent tumor progression and control abnormal steroidogenesis. In the case of food-dependent $\mathrm{CS}$, due to aberrant expression of the GIP receptor, somatostatin analogs have been used to control cortisol secretion $(2,16)$.

We prospectively evaluated the presence of aberrant receptor responses in a large cohort of 32 consecutive patients with bilateral macronodular adrenal hyperplasia. The present study shows that, independent of the functional status, aberrant receptors are highly prevalent. In our series, a response to the standard mixed meal was specific to patients with overt CS. Interestingly, a cortisol response to provocative testing with glucagon was observed in a large proportion of patients with SCS. In addition, a significant cortisol inhibition was obtained by the administration of a somatostatin analog, especially in the SCS group.

\section{Patients and methods}

\section{Patients}

Thirty-two consecutive patients ( 23 women and 9 men) with bilateral macronodular adrenal hyperplasia, referred to our Endocrine Unit, have been investigated between January 1999 and October 2008. Bilateral macronodular hyperplasia was defined on the basis of the computed tomographic appearance. Two radiological aspects were encountered. In some patients, adrenal glands were massively but smoothly enlarged with a dominant nodule. In other patients, multiple bilateral adrenocortical macronodules up to $5 \mathrm{~cm}$ in diameter were presented. Normal, uninvolved adrenal gland could not be identified. The main clinical characteristics and initial endocrine investigations are summarized in Table 1.

Baseline hormonal investigations were performed: 24-h urinary cortisol, diurnal variation in serum cortisol, 1-mg overnight dexamethasone suppression test, plasma aldosterone to renin concentration ratio for patients with high blood pressure, testosterone, dehydroepiandrosterone sulfate, estradiol, compound S, desoxycorticosterone, baseline and post-corticotrophin serum cortisol and 17-hydroxyprogesterone, and plasma ACTH and cortisol levels before and after i.v. administration of $1 \mu \mathrm{g} / \mathrm{kg}$ ovine $\mathrm{CRH}$ (oCRH). Assays were performed as previously reported (17-19).

The diagnosis of CS was made on the basis of elevated daily urinary free cortisol $(>90 \mu \mathrm{g} /$ day $)$, non-suppressibility of serum cortisol after 1-mg dexamethasone testing $(>50 \mathrm{nmol} / \mathrm{l})$ and suppressed plasma ACTH (both basally and after administration of $1 \mu \mathrm{g} / \mathrm{kg}$ of oCRH).

The definition of subclinical Cushing relies on an abnormal 1-mg overnight dexamethasone suppression test (serum cortisol level $>50 \mathrm{nmol} / \mathrm{l}$ ) and normal 24-h urinary cortisol.

In the 13 operated patients, AIMAH was histologically proven. Multiple nodules or diffuse hyperplasia were recognized with no residual normal adrenal cortex. Non-nodular atrophic adrenal cortex could be detected in some AIMAH.

The study was approved by and was performed according to the recommendations of the Institutional Review Board of Cochin Hospital. Written informed consent was obtained from all the patients.

\section{Provocative tests for the detection of aberrant receptor expression}

The protocol used to detect in vivo cortisol responses indicative of aberrant adrenal receptors was modified from that originally described by Lacroix et al. (12). Two approaches were added in the present study: patients were asked to provide salivary samples during the provocative tests for the measurement of salivary cortisol; an acute octreotide test was performed. The investigation protocol was conducted over a 4-day period, after discontinuing potential interfering medications at least 1 week before the studies. The strategy consisted of either inducing transient modulation of endogenous ligands for potentially aberrant adrenocortical receptors or directly administering compounds acting at these potential receptors, and secondarily monitoring the steroidogenic responses (serum and salivary cortisol).

On day 1, a supine-to-upright posture test evaluated the potential modulation by angiotensin-II, vasopressin, catecholamines, endothelin, or natriuretic peptide. This was followed by a standard mixed meal, assessing adrenal receptors for GIP. Subsequently, i.v. injection of $250 \mu \mathrm{g}$ ACTH 1-24 provided a reference for the adrenal steroidogenic response.

On day 2, administration of $100 \mu \mathrm{g}$ GnRH i.v. was used to assess the potential modulation of cortisol by FSH, LH, or GnRH. A bolus injection of $200 \mu \mathrm{g}$ TRH i.v. was used to evaluate the adrenal presence of TSH, prolactin, or TRH receptors. Subsequently, $10 \mathrm{mg}$ of metoclopramide (Primpéran, Synthélabo Laboratories, 


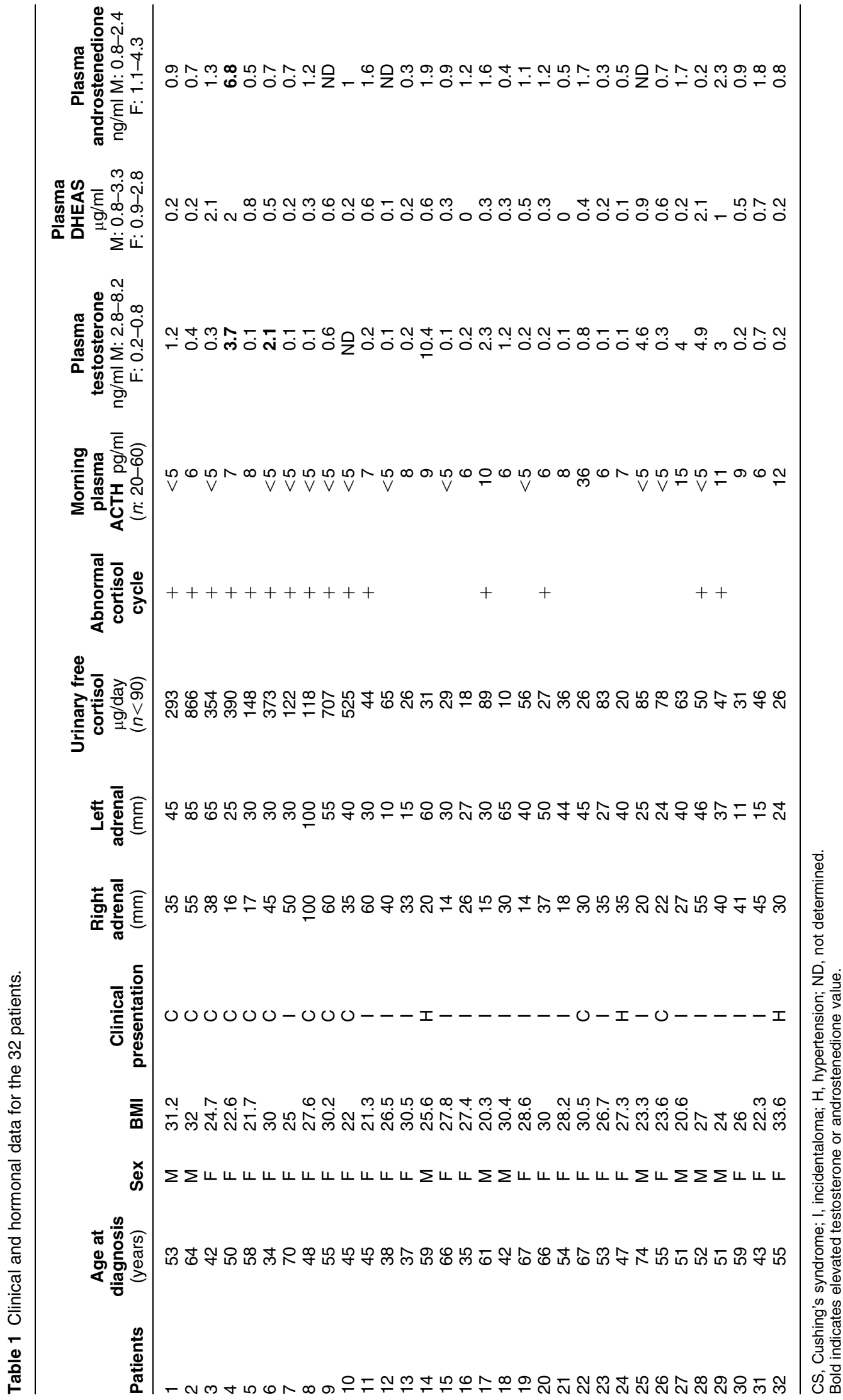


Meudon-la-Forêt, France) i.v., a serotonin 5-HT4 receptor agonist, was used. On day 3 , the tests included the i.m. administration of $1 \mathrm{mg}$ glucagon in the morning. The somatostatin analog octreotide $100 \mu \mathrm{g}$ (Sandostatin, Novartis) was subsequently administered subcutaneously in the afternoon after $1 \mathrm{~h}$ in the supine position. Serial ACTH and cortisol measurements were taken at 60 -min intervals for $4-5 \mathrm{~h}$ during the test. ACTH concentrations showed no significant variation.

Finally, on day 4, administration of $0.5 \mathrm{mg}$ terlipressin (a precursor of lysine vasopressin; Glypressine, Ferring Laboratories) i.v. assessed the response of cortisol to vasopressin receptors.

To interpret the responses, we expressed the serum cortisol concentrations at the peak or nadir time point during the various tests, as percent change from basal levels. In accordance with previous reports $(12,15,20)$, a change in plasma cortisol $<25 \%$ from baseline (arbitrarily considered $100 \%$ ) was defined as no response; a $25-49 \%$ change as partial response; and a change of $50 \%$ or greater as a positive response.

\section{Statistical analysis}

Quantitative variables were described using means and S.D. Qualitative variables were described using percent. Owing to non-normal distribution of several variables and small numbers of subjects in groups of interest, nonparametric statistical methods were used to examine relationships between variables when appropriate (Fisher's exact $\chi^{2}$ test, Wilcoxon test, and pairwise Wilcoxon test). Two-tailed $P$ values were used. $P$ values below 0.05 were considered to indicate significance.

\section{Results}

\section{Demographics}

The mean age between the CS group and the SCS group was not significantly different $(51.9 \pm 10.6$ vs 53.5 $\pm 10.8, P=0.64$; Table 1$)$. The overall gender distribution showed a female predominance $(71.8 \%)$, similar to what has been reported for adrenal adenomas in other studies.

\section{Clinical characteristics and hormonal evaluations}

The mean body mass index of the patients was 26.5 $\pm 3.6 \mathrm{~kg} / \mathrm{m}^{2}$ without statistical differences between the two groups $(P=0.82$; Table 1$)$.

The clinical presentation varied greatly among the two groups. Except one with an incidentaloma, all the patients in the CS group had clinical manifestations of cortisol excess. On the contrary, patients from the SCS group were almost all investigated after the incidental discovery of bilateral adrenal masses.

Adrenal size ranged from 17 to $100 \mathrm{~mm}$ (mean $47.8 \pm 23.6 \mathrm{~mm})$ in the CS group and from 11 to $65 \mathrm{~mm}$ (mean $32.3 \pm 8.8 \mathrm{~mm}$ ) in the SCS group. The difference between the two means was not statistically significant $(P=0.06)$.

The initial hormonal evaluation allowed us to identify 10 patients with an overt CS and 22 patients with a SCS. As expected by definition, the mean urinary cortisol was significantly higher in the CS group than in SCS group $(389.6 \pm 249.6$ vs $44.8 \pm 23.5 \mu \mathrm{g} /$ day, $P=0.0001)$. Serum cortisol circadian variations were lost in all the patients with CS, and in only five patients with SCS. Plasma ACTH levels were significantly lower in the CS group than in the SCS group $(5.6 \pm 1.1$ vs $8.7 \pm 6.6 \mathrm{pg} / \mathrm{ml}, P=0.025$ ).

Most of the patients had low DHEAS levels, probably at least partially related to the low ACTH levels. Two females in the CS group had high testosterone levels. Two male patients in each group had low testosterone levels. Primary hyperaldosteronism was not observed (data not shown).

Administration of ACTH 1-24 provoked a greater percent rise in serum cortisol in the SCS group than in the CS group $(461.7 \pm 278.9$ vs $111.6 \pm 105.6 \%$, $P=0.0005$ ) (Fig. 1a). This may explain the similar serum cortisol concentrations at 60 min post ACTH administration in the CS and SCS groups respectively $(487.6 \pm 168.7$ vs $412 \pm 123 \mathrm{ng} / \mathrm{ml}, P=0.24)$.

Baseline 17-OHP levels were higher in the CS group than in the SCS group $(3.1 \pm 2.8$ vs $0.55 \pm 0.59 \mathrm{ng} / \mathrm{ml}$, $P=0.002$ ), but after the administration of ACTH 1-24, the percent increase was higher in the SCS group than in the CS group $(3153.5 \pm 2688$ vs $420 \pm 542.2, P=0.003$; Fig. 1b). Interestingly, 6 of the 32 patients had post-ACTH serum 17-OHP levels above $10 \mathrm{ng} / \mathrm{l}$, suggesting a decreased activity of the 21-hydroxylase enzyme.

Among the 32 patients, 13 underwent surgery: the ten patients with CS (bilateral adrenalectomy) and three patients with SCS (unilateral adrenalectomy for asymmetrical adrenal enlargement) (Table 2). In all the cases, the pathology confirmed the definitive diagnosis of AIMAH.

\section{In vivo evaluation for the presence of aberrant adrenal hormone receptors}

Figure 2 shows the maximum serum cortisol variations (peak or nadir) during the various tests, shown as percent change from baseline. The two groups, CS and SCS patients, were analysed separately to compare the prevalence of responsive patients in relation to the functional status. Among the six provocative tests, a significant difference in the response rates between the two groups was only observed with the mixed meal. A response to the mixed meal was only observed for three patients in the CS group. A response to glucagon was observed in 

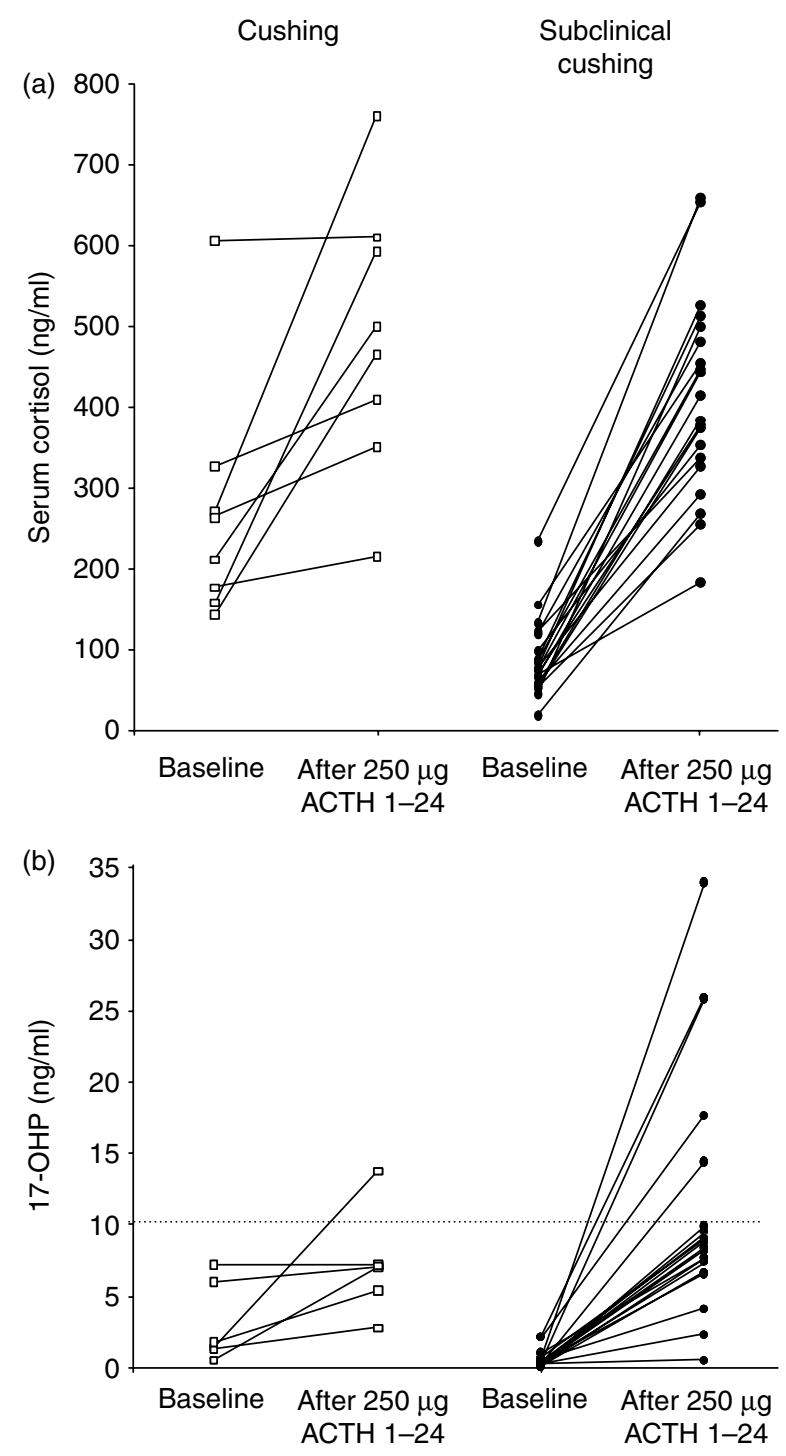

Figure 1 (a) Response of serum cortisol after the administration of $250 \mu \mathrm{g} \mathrm{ACTH}$ in patients with CS (white boxes) and with SCS (black dots). (b) Response of serum 17-OHP after the administration of $250 \mu \mathrm{g} \mathrm{ACTH}$ in patients with CS (white boxes) and with SCS (black dots).

one patient in the CS group and in seven patients in the SCS group, without reaching statistical significance.

Table 2 shows the responses to the six provocative tests for each patient of the two groups. Excluding four patients (two CS and two SCS), all the others showed at least one positive response to one provocative test. The most frequent responses were found for the upright posture $(67 \%)$, metoclopramide $(56 \%)$, and the glucagon test $(47 \%)$, whereas the mixed meal was the test with the lowest response frequency (12\%). Many tumors responded to several provocative tests, yet the pattern of receptors expression was not in favor of a specific association. The posture test evaluates the potential roles of various ligands, including
angiotensin-II, vasopressin, and catecholamines. It is worth noting that a response to terlipressin (vasopressin analog) was present in five of six patients who also responded to the posture.

Following the initial screening protocol, a confirmatory test was undertaken in nine patients with a positive response. The responses were confirmed, except in one patient with a response to the standard mixed meal (not included among the positive responses). A serum cortisol response to the GnRH and TRH tests leads to a further stimulatory test. Cortisol regulation by the LH receptor was investigated by the in vivo administration of hCG.

The investigation protocol was completed with an acute octreotide inhibition test. Twenty patients were evaluated (7 in the CS group and 13 in the SCS group). Overall, using the arbitrary threshold of at least $25 \%$, a serum cortisol decrease was observed in two-thirds of the patients (Table 2). Interestingly, among the seven investigated patients in the CS group, only the three patients with a food-dependent CS presented a significant cortisol response (Fig. 2). In the SCS group, an inhibition was observed for 12 of 13 tested patients (92\%) (Fig. 2).

\section{Discussion}

Bilateral adrenocortical hyperplasia is a rare cause of excess corticosteroid secretion. This study comprises a large series of AIMAH patients accumulated over 9 years. Two main AIMAH diagnostic groups were identified: patients with a bilateral adrenal incidentalomas and those with an overt CS.

Indeed, most of the AIMAH were incidentally discovered during diagnostic imaging. Low attenuation value on unenhanced computed tomography scan confirmed the presence of fat within the masses, already suggesting their adrenocortical origin (21), and subtle dysregulation of cortisol secretion is a further evidence in support of an AIMAH.

Multiple bilateral adrenocortical macronodules in the presence of an overt CS are practically pathognomonic of AIMAH. In our series, ten patients met these criteria. A simultaneous bilateral laparoscopic adrenalectomy was performed. The preoperative diagnosis of AIMAH was confirmed in each case by histological examination.

The 22 remaining patients had bilateral adrenal enlargement with subtle evidence for cortisol autonomy. Unilateral laparoscopic adrenalectomy was performed for three patients with an highly asymmetrical hyperplasia. AIMAH was confirmed by the histological analysis. This is in agreement with the fact that bilateral adrenocortical hyperplasias with SCS are mostly AIMAH (22).

The two main differential diagnoses of bilaterally enlarged nodular adrenocortical glands are longstanding Cushing's disease with chronic stimulation of the adrenal cortex and congenital adrenal hyperplasia 
Table 2 Profile of aberrant regulations per patient. The four patients without any response are indicated by bold. For the six provocative tests, the numbers inside the cells correspond to the relative serum cortisol increase as percent from basal levels (considered positive if $>125 \%$ ). For the acute octreotide inhibition test, the numbers represent the percent of inhibition (considered positive if $>25 \%$ ).

\begin{tabular}{|c|c|c|c|c|c|c|c|c|c|c|}
\hline \multirow[b]{2}{*}{$\begin{array}{l}\text { Patients } \\
(n=32)\end{array}$} & \multirow[b]{2}{*}{$\begin{array}{c}\text { Functional } \\
\text { status }\end{array}$} & \multirow[b]{2}{*}{$\begin{array}{l}\text { Operated } \\
(n=13)\end{array}$} & \multicolumn{6}{|c|}{ Stimulation tests } & \multirow{2}{*}{$\begin{array}{l}\text { Number of } \\
\text { positive } \\
\text { responses } \\
\text { per patient }\end{array}$} & \multirow[b]{2}{*}{$\begin{array}{c}\text { Inhibition } \\
\text { by } \\
\text { octreotide }\end{array}$} \\
\hline & & & Upright & $\begin{array}{l}\text { Mixed } \\
\text { meal }\end{array}$ & $\begin{array}{l}\text { GnRH/ } \\
\text { TRH }\end{array}$ & $\begin{array}{l}\text { Metoclo- } \\
\text { pramide }\end{array}$ & Glucagon & Terlipressin & & \\
\hline 1 & \multirow{10}{*}{$\begin{array}{l}\text { Cushing } \\
\qquad(n=10)\end{array}$} & + & 148 & - & - & 133 & ND & ND & $2 / 4$ & - \\
\hline 2 & & + & 181 & - & ND & ND & ND & ND & $1 / 2$ & ND \\
\hline 3 & & + & - & 348 & - & - & - & ND & $1 / 4$ & 28 \\
\hline 4 & & + & - & - & - & - & - & ND & $0 / 5$ & - \\
\hline 5 & & + & - & - & - & - & ND & ND & $0 / 4$ & - \\
\hline 6 & & + & 167 & - & - & 184 & ND & 152 & $3 / 4$ & - \\
\hline 7 & & + & 170 & ND & - & 204 & ND & ND & $2 / 3$ & ND \\
\hline 8 & & + & 140 & - & - & - & - & ND & $1 / 5$ & ND \\
\hline 9 & & + & 464 & 490 & 295 & - & - & ND & $3 / 5$ & 26 \\
\hline 10 & & + & 129 & 586 & 563 & - & 147 & - & $4 / 6$ & 25 \\
\hline 11 & \multirow{24}{*}{$\begin{array}{l}\text { Subclinical } \\
\qquad(n=22)\end{array}$} & + & 144 & - & - & 438 & 127 & 178 & $4 / 6$ & 71 \\
\hline 12 & & + & - & - & 154 & - & 163 & ND & $2 / 5$ & ND \\
\hline 13 & & + & 253 & - & - & 185 & 231 & ND & $3 / 5$ & 34 \\
\hline 14 & & & - & - & - & 426 & - & ND & $1 / 5$ & 71 \\
\hline 15 & & & - & - & - & 209 & 224 & ND & $2 / 5$ & 72 \\
\hline 16 & & & - & - & - & 180 & ND & ND & $1 / 4$ & ND \\
\hline 17 & & & 137 & ND & - & - & ND & ND & $1 / 3$ & ND \\
\hline 18 & & & ND & ND & 125 & ND & 146 & 212 & $3 / 3$ & 57 \\
\hline 19 & & & 225 & - & - & 209 & ND & ND & $2 / 4$ & 70 \\
\hline 20 & & & 227 & - & 215 & - & ND & ND & $2 / 4$ & 57 \\
\hline 21 & & & 192 & - & - & 137 & - & 196 & $3 / 6$ & 52 \\
\hline 22 & & & 222 & - & 128 & - & ND & ND & $2 / 4$ & ND \\
\hline 23 & & & 162 & - & - & 310 & ND & 241 & $3 / 5$ & ND \\
\hline 24 & & & - & ND & - & - & ND & ND & $0 / 3$ & ND \\
\hline 25 & & & 152 & - & - & 160 & ND & ND & $2 / 4$ & ND \\
\hline 26 & & & - & ND & 129 & - & - & ND & $1 / 4$ & 50 \\
\hline 27 & & & 159 & ND & - & 206 & ND & ND & $2 / 3$ & ND \\
\hline 28 & & & 168 & - & 239 & 138 & 147 & ND & $4 / 5$ & 64 \\
\hline 29 & & & 129 & - & - & 183 & - & 223 & $3 / 6$ & 37 \\
\hline 30 & & & - & - & - & - & ND & ND & $0 / 4$ & ND \\
\hline 31 & & & 148 & - & - & 154 & 289 & - & $3 / 6$ & 28 \\
\hline \multirow[t]{3}{*}{32} & & & 503 & - & - & 183 & - & ND & $2 / 5$ & - \\
\hline & & & $21 / 31$ & $3 / 25$ & $8 / 31$ & $17 / 30$ & $8 / 17$ & $\begin{array}{l}6 / 8 \\
75 \%\end{array}$ & & $15 / 20$ \\
\hline & & & \multicolumn{8}{|c|}{ Percentage of positive responses per test } \\
\hline
\end{tabular}

Cells with a dash indicate the lack of response. ND, not done (patients with contraindications to the test: hypertension, diabetes, etc).

(CAH) due to 21-hydroxylase deficiency. In our series, the diagnosis of Cushing's disease is very unlikely based on the radiological imaging criteria and the low ACTH levels in our patients. Late onset 21-hydroxylase deficiency is occasionally revealed by the discovery of bilateral incidentalomas (23). Most of our patients underwent an ACTH stimulation test, and an exaggerated 17-OHP response was observed in one patient with CS and in five patients with SCS. Low expression of the normal enzyme within the tumor is the more likely explanation, as has been shown by Racz et al. (24) in 12 adrenocortical adenomas; the normal baseline 17-OHP levels and the robust cortisol response also argue against $\mathrm{CAH}$. These patients were indeed genotyped, with no evidence of a mutated 21-hydroxylase gene.
The mean age of our patients (53 years) at presentation is another clinical feature in favor of AIMAH (25). Primary pigmented nodular adrenocortical disease, another form of bilateral ACTH-independent CS, occurs at an earlier age.

Most AIMAH cases are sporadic, but some patients have been reported with a familial form of the disease (26). In our series, four patients had relatives with AIMAH (data not shown). A systematic screening of family members of all our patients may identify additional cases with bilateral adrenocortical hyperplasia and SCS.

Two female patients had an increase in testosterone levels. Androgen levels returned to normal after bilateral adrenalectomy. Androgen production has been described in patients with AIMAH and LH receptor 


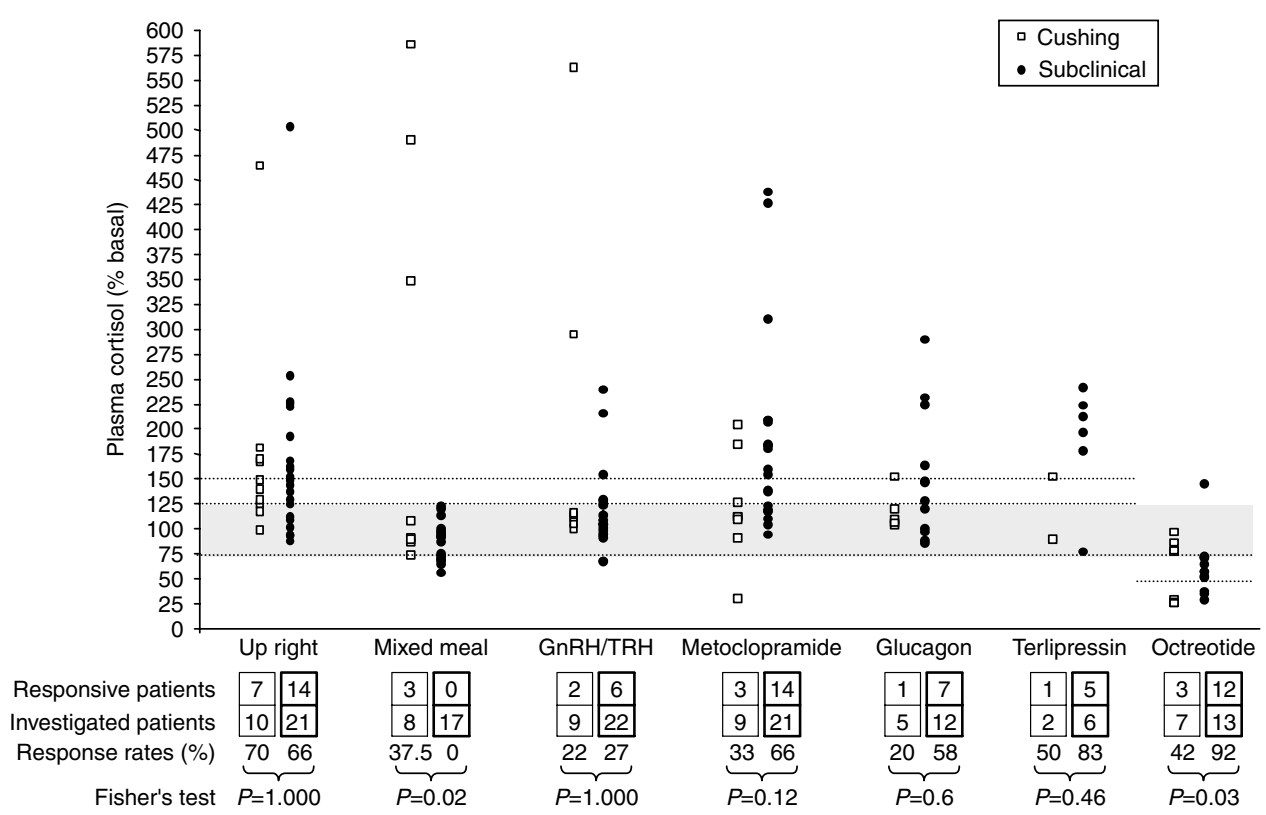

Figure 2 Serum cortisol responses to the various tests in the groups of 10 patients with CS (white boxes) and 22 patients with SCS (black dots). Results are expressed as percent of the serum cortisol concentrations observed at the peak or nadir time point during the various tests, as compared to basal levels (100\%). Tests included a 2-h ambulation posture test, a standard mixed meal, administration of GnRH $(100 \mu$ g i.v.) and TRH (200 $\mu$ g i.v.), glucagon (1 mg i.v.), terlipressin (10 IU i.m.), and metoclopramide (10 mg i.v). The two upper lines indicate the thresholds for partial (125\%) and positive (150\%) responses. The two lower lines indicate the thresholds for partial $(75 \%)$ and complete $(50 \%)$ octreotide inhibition.

expression $(27,28)$. The lack of response to the GnRH test in our two patients suggests that other mechanisms are involved in adrenal androgen synthesis. Conversely, some male patients had low testosterone levels. Reversibility after the correction of hypercortisolism is in favor of a relative suppression of the gonadotropic axis by cortisol excess.

The concept of aberrant receptors, functionally coupled to steroidogenesis, has been firmly established in AIMAH (29). A protocol designed to screen patients for the presence of these aberrant receptors should be undertaken in all patients with AIMAH. The identification of aberrant adrenal hormone receptors can provide different opportunities. First, it might help to reinforce the diagnosis of AIMAH because aberrant cortisol regulation, not specific to bilateral adrenocortical hyperplasia, could be more prevalent in AIMAH (15). Unilateral cortisol-secreting adenomas were not included in this study, so we are unable to compare the prevalence of aberrant receptors between bilateral and unilateral benign adrenocortical tumors. Large series of patients with AIMAH are necessary to define the true prevalence of aberrant hormone receptor responses. Second, it might allow the identification of specific targets for pharmacological therapies as an alternative to bilateral adrenalectomy. Third, thorough phenotyping might uncover new pathophysiological mechanisms.

Our large series confirms the large prevalence of aberrant receptor expression in AIMAHs $(1,15,20)$.
Using the arbitrary threshold of $25 \%$ for a partial response, aberrant cortisol regulation was observed in 28 of $32(87 \%)$ patients. Moreover, 21 of the $28(75 \%)$ patients showed aberrant responses to two or more provocative test. Responses to the posture test and to metoclopramide were observed in 14 of the $21(66 \%)$ patients showing two or more responses. The present study demonstrates, again on a large series, that vasopressin and serotonin receptors are probably the more prevalent functional receptors in AIMAH. This is in accordance with previous reports $(11,20,30)$.

A cortisol response following glucagon administration has been found in patients with unilateral adenoma $(1,13,26)$. One patient with AIMAH and cortisol stimulation by glucagon was reported (31). In previous large series, none of the six patients (15) or ten patients (1) with AIMAH had plasma cortisol increases after the administration of glucagon. In the present study, eight patients had a cortisol response after glucagon injection. This may be due to the high number of patients with SCS in our series. Indeed, seven of the eight glucagon-responsive patients were in the SCS group. Systematic in vitro characterization of the different receptors involved was not possible because most of the patients had SCS and were not operated on. For some operated patients, studies were conducted to correlate the in vivo responses with in vitro data (previously published in $(6,14,18,32)$ ). Aberrant expression of the GIP receptor in AIMAH tissues was confirmed in the three food-dependent CS patients. 
In two patients with a cortisol response to the GnRH test, hCG stimulated the cortisol secretion in vitro. A hyperresponsiveness of hyperplastic adrenal tissues to serotonin, angiotensin II, and arginine vasopressin was also demonstrated.

Because high cortisol secretion could mask the action of some endogenous ligands for aberrant receptors (relative suppression of ligands by steroids), it was important to take into account the functional status. There was no statistically significant difference in the prevalence of aberrant responses between the two groups of patients with AIMAH, except for the mixed meal responses that were specifically observed in the CS group. One hypothesis would be that some specific aberrant receptors may lead more frequently to a CS.

In the present study, the clinical and biological features allowed us to subclassify the patients with AIMAH in two groups according to their initial presentation: those with bilateral adrenal incidentaloma who were subsequently found to have mild autonomous cortisol hyperproduction, and those with overt CS who were subsequently found to have ACTHindependent hypercortisolism with bilateral adrenal lesions. An important issue is to know if these two patient groups reflect a disease continuum starting with subtle cortisol excess and then over time going to CS, or reflect two different disease entities. The same global prevalence of aberrant receptor responses in the two groups may be viewed as evidence for a unique disease. However, this interpretation should be treated with some caution in view of some distinct patterns of expressed receptor: a response to the mixed meal was observed only for three patients in the CS group. Conversely, a cortisol response to glucagon was present more frequently in the SCS group, without reaching statistical significance. Moreover, the lack of significant differences between the two groups in age and adrenal tumor size may be considered as an argument against the continuum hypothesis. Indeed, if it reflected simply two different stages of the same chronic disease, one would assume that the patients in the SCS group were younger at the diagnosis and had smaller adrenal tumor than the patients in the CS group. AIMAH is a heterogenous disease both clinically and genetically. Exploring the underlying molecular cause should help resolve this key question.

Targeting a pharmacological therapy that could counteract the SCS in AIMAH is an important goal. Understanding AIMAH pathophysiology might pave the way for future clinical trials. Indeed, CS control was demonstrated with chronic s.c. octreotide administration in patients with food-dependent CS $(2,27,33,34)$. One patient with a food-dependent CS in our series was efficiently treated with octreotide for several weeks. A biochemical relapse lead to a bilateral adrenalectomy. Endogenous GIP levels inhibition is thought to be the underlying mechanism. The acute octreotide test performed in the present study, showing cortisol inhibition specifically in the three CS patients with a response to mixed meal, reinforces the GIP inhibition hypothesis. To our knowledge, there has been no previous study with a systematic testing of the cortisol response after an acute injection of octreotide. The results observed in the SCS group are interesting to discuss, even if a spontaneous serum cortisol decrease due to the circadian rhythm or an indirect action via the inhibition of ACTH cannot be ruled out. Other mechanisms may explain the octreotide cortisol inhibition. None of the patients responsive to the somatostatin analog in the SCS group had a response to the mixed meal. Octreotide inhibition of other endogenous ligands for aberrant receptors could be an alternate hypothesis. Octreotide is known to inhibit the release of glucagon, which may be a candidate endogenous ligand. It is worth noting that all the glucagonresponsive patients had an inhibition of cortisol secretion by octreotide. Direct targeting of somatostatin receptors expressed in adrenal tissues should not be ruled out. Some reports suggest somatostatin receptors expression in adrenocortical tumors. Octreotide binds with high affinity to type 2 somatostatin receptor. This receptor was one of the different subtypes expressed in both non-functioning and cortisol-secreting adenomas (35). Future studies should be conducted to test somatostatin receptor expression of the available excised tissue. Finally, somatostatin receptors expression on human lymphocytes should be kept in mind, because adrenal lymphocytic infiltration may be found in adrenocortical tumors (36).

In conclusion, this is the largest series of AIMAHs that were systematically screened for aberrant hormone responses. It allowed us to demonstrate the high prevalence of aberrant responses in both the CS and SCS groups. A cortisol response to glucagon may be more frequent than anticipated, particularly in AIMAH with SCS. Thorough phenotyping of this rare condition may help uncover the underlying pathophysiology. The acute inhibition of cortisol secretion with the somatostatin analog octreotide in the SCS group should lead to further studies to determine its mechanism.

\section{Declaration of interest}

The authors declare that there is no conflict of interest that could be perceived as prejudicing the impartiality of the research reported.

\section{Funding}

This work was supported by the COMETE Network (Programme Hospitalier de Recherche Clinique Grant AOM95201), the Assistance Publique-Hôpitaux de Paris (Clinical Research Center Grant 02005 to L Groussin), and the Conny-Maeva Charitable Foundation. This research did not receive any specific grant from any funding agency in the commercial or not-for-profit sector.

\section{Acknowledgements}

We thank all the physicians for referring their patients. 


\section{References}

1 Hsiao HP, Kirschner LS, Bourdeau I, Keil MF, Boikos SA, Verma S, Robinson-White AJ, Nesterova M, Lacroix A \& Stratakis CA. Clinical and genetic heterogeneity, overlap with other tumor syndromes, and atypical glucocorticoid hormone secretion in adrenocorticotropin-independent macronodular adrenal hyperplasia compared with other adrenocortical tumors. Journal of Clinical Endocrinology and Metabolism 200994 2930-2937.

2 Reznik Y, Allali-Zerah V, Chayvialle JA, Leroyer R, Leymarie P, Travert G, Lebrethon MC, Budi I, Balliere AM \& Mahoudeau J. Food-dependent Cushing's syndrome mediated by aberrant adrenal sensitivity to gastric inhibitory polypeptide. New England Journal of Medicine 1992327 981-986.

3 Lacroix A, Bolte E, Tremblay J, Dupre J, Poitras P, Fournier H, Garon J, Garrel D, Bayard F, Taillefer R, Flanagan RJ \& Hamet P. Gastric inhibitory polypeptide-dependent cortisol hypersecretion a new cause of Cushing's syndrome. New England Journal of Medicine 1992327 974-980.

4 Lacroix A, Tremblay J, Rousseau G, Bouvier M \& Hamet P. Propranolol therapy for ectopic beta-adrenergic receptors in adrenal Cushing's syndrome. New England Journal of Medicine 1997337 1429-1434.

5 Horiba N, Suda T, Aiba M, Naruse M, Nomura K, Imamura M \& Demura H. Lysine vasopressin stimulation of cortisol secretion in patients with adrenocorticotropin-independent macronodular adrenal hyperplasia. Journal of Clinical Endocrinology and Metabolism 199580 2336-2341.

6 Louiset E, Contesse V, Groussin L, Cartier D, Duparc C, Barrande G, Bertherat J, Vaudry H \& Lefebvre H. Expression of serotonin7 receptor and coupling of ectopic receptors to protein kinase A and ionic currents in adrenocorticotropin-independent macronodular adrenal hyperplasia causing Cushing's syndrome. Journal of Clinical Endocrinology and Metabolism 200691 4578-4586.

7 Nakamura Y, Son Y, Kohno Y, Shimono D, Kuwamura N, Koshiyama H, Sasano H \& Matsuda T. Case of adrenocorticotropic hormone-independent macronodular adrenal hyperplasia with possible adrenal hypersensitivity to angiotensin II. Endocrine 2001 15 57-61.

8 Lacroix A, Hamet P \& Boutin JM. Leuprolide acetate therapy in luteinizing hormone-dependent Cushing's syndrome. New England Journal of Medicine 1999341 1577-1581.

9 Pralong FP, Gomez F, Guillou L, Mosimann F, Franscella S \& Gaillard RC. Food-dependent Cushing's syndrome: possible involvement of leptin in cortisol hypersecretion. Journal of Clinical Endocrinology and Metabolism 199984 3817-3822.

10 Lacroix A, Tremblay J, Touyz RM, Deng LY, Lariviere R, Cusson JR, Schiffrin EL \& Hamet P. Abnormal adrenal and vascular responses to vasopressin mediated by a V1-vasopressin receptor in a patient with adrenocorticotropin-independent macronodular adrenal hyperplasia. Cushing's syndrome, and orthostatic hypotension. Journal of Clinical Endocrinology and Metabolism $1997 \mathbf{8 2}$ 2414-2422.

11 Cartier D, Lihrmann I, Parmentier F, Bastard C, Bertherat J, Caron P, Kuhn JM, Lacroix A, Tabarin A, Young J, Vaudry H \& Lefebvre H. Overexpression of serotonin 4 receptors in cisaprideresponsive adrenocorticotropin-independent bilateral macronodular adrenal hyperplasia causing Cushing's syndrome. Journal of Clinical Endocrinology and Metabolism 200388 248-254.

12 Lacroix A, Mircescu H \& Harriet P. Clinical evaluation of the presence of abnormal hormone receptors in adrenal Cushing's syndrome. Endocrinologist 1999 9 9-15.

13 Reznik Y, Lefebvre H, Rohmer V, Charbonnel B, Tabarin A, Rodien P, Lecomte P, Bardet S, Coffin C \& Mahoudeau J. Aberrant adrenal sensitivity to multiple ligands in unilateral incidentaloma with subclinical autonomous cortisol hypersecretion: a prospective clinical study. Clinical Endocrinology 200461 311-319.
14 Groussin L, Perlemoine K, Contesse V, Lefebvre H, Tabarin A, Thieblot P, Schlienger JL, Luton JP, Bertagna X \& Bertherat J. The ectopic expression of the gastric inhibitory polypeptide receptor is frequent in adrenocorticotropin-independent bilateral macronodular adrenal hyperplasia, but rare in unilateral tumors. Journal of Clinical Endocrinology and Metabolism $2002 \mathbf{8 7}$ 1980-1985.

15 Mircescu H, Jilwan J, N'Diaye N, Bourdeau I, Tremblay J, Hamet P \& Lacroix A. Are ectopic or abnormal membrane hormone receptors frequently present in adrenal Cushing's syndrome? Journal of Clinical Endocrinology and Metabolism $2000 \mathbf{8 5}$ $3531-3536$.

16 de Herder WW, Hofland LJ, Usdin TB, de Jong FH, Uitterlinden P, van Koetsveld P, Mezey E, Bonner TI, Bonjer HJ \& Lamberts SW. Food-dependent Cushing's syndrome resulting from abundant expression of gastric inhibitory polypeptide receptors in adrenal adenoma cells. Journal of Clinical Endocrinology and Metabolism $1996813168-3172$.

17 Luton JP, Martinez M, Coste J \& Bertherat J. Outcome in patients with adrenal incidentaloma selected for surgery: an analysis of 88 cases investigated in a single clinical center. European Journal of Endocrinology $2000143111-117$.

18 Bertherat J, Contesse V, Louiset E, Barrande G, Duparc C, Groussin L, Emy P, Bertagna X, Kuhn JM, Vaudry H \& Lefebvre $\mathrm{H}$. In vivo and in vitro screening for illegitimate receptors in adrenocorticotropin-independent macronodular adrenal hyperplasia causing Cushing's syndrome: identification of two cases of gonadotropin/gastric inhibitory polypeptide-dependent hypercortisolism. Journal of Clinical Endocrinology and Metabolism 2005 $901302-1310$

19 d'Alva CB, Abiven-Lepage G, Viallon V, Groussin L, Dugue MA, Bertagna X \& Bertherat J. Sex steroids in androgen-secreting adrenocortical tumors: clinical and hormonal features in comparison with non-tumoral causes of androgen excess. European Journal of Endocrinology 2008159 641-647.

20 Bourdeau I, D'Amour P. Hamet P. Boutin JM \& Lacroix A. Aberrant membrane hormone receptors in incidentally discovered bilateral macronodular adrenal hyperplasia with subclinical Cushing's syndrome. Journal of Clinical Endocrinology and Metabolism 2001 86 5534-5540.

21 Doppman JL, Chrousos GP, Papanicolaou DA, Stratakis CA, Alexander HR \& Nieman LK. Adrenocorticotropin-independent macronodular adrenal hyperplasia: an uncommon cause of primary adrenal hypercortisolism. Radiology $2000 \mathbf{2 1 6}$ 797-802.

22 Mazzuco TL, Bourdeau I \& Lacroix A. Adrenal incidentalomas and subclinical Cushing's syndrome: diagnosis and treatment. Current Opinion in Endocrinology, Diabetes and Obesity 200916 203-210.

23 Patocs A, Toth M, Barta C, Sasvari-Szekely M, Varga I, Szucs N, Jakab C, Glaz E \& Racz K. Hormonal evaluation and mutation screening for steroid 21-hydroxylase deficiency in patients with unilateral and bilateral adrenal incidentalomas. European Journal of Endocrinology 2002147 349-355.

24 Racz K, Pinet F, Marton T, Szende B, Glaz E \& Corvol P. Expression of steroidogenic enzyme messenger ribonucleic acids and corticosteroid production in aldosterone-producing and "nonfunctioning" adrenal adenomas. Journal of Clinical Endocrinology and Metabolism 199377 677-682.

25 Swain JM, Grant CS, Schlinkert RT, Thompson GB, vanHeerden JA, Lloyd RV \& Young WF. Corticotropin-independent macronodular adrenal hyperplasia: a clinicopathologic correlation. Archives of Surgery 1998133 541-545 discussion 545-546.

26 Lacroix A. ACTH-independent macronodular adrenal hyperplasia. Best Practice \& Research. Clinical Endocrinology \& Metabolism 2009 23 245-259.

27 Albiger NM, Occhi G, Mariniello B, Iacobone M, Favia G, Fassina A, Faggian D, Mantero F \& Scaroni C. Food-dependent Cushing's syndrome: from molecular characterization to therapeutical results. European Journal of Endocrinology 2007 $157771-778$. 
28 Goodarzi MO, Dawson DW, Li X, Lei Z, Shintaku P, Rao CV \& Van Herle AJ. Virilization in bilateral macronodular adrenal hyperplasia controlled by luteinizing hormone. Journal of Clinical Endocrinology and Metabolism $2003 \mathbf{8 8} 73-77$.

29 Lacroix A, Ndiaye N, Tremblay J \& Hamet P. Ectopic and abnormal hormone receptors in adrenal Cushing's syndrome. Endocrine Reviews 200122 75-110.

30 Vezzosi D, Cartier D, Regnier C, Otal P, Bennet A, Parmentier F, Plantavid M, Lacroix A, Lefebvre H \& Caron P. Familial adrenocorticotropin-independent macronodular adrenal hyperplasia with aberrant serotonin and vasopressin adrenal receptors. European Journal of Endocrinology 2007156 21-31.

31 Matsukura S, Kakita T, Sueoka S, Yoshimi H, Hirata Y, Yokota M \& Fujita T. Multiple hormone receptors in the adenylate cyclase of human adrenocortical tumors. Cancer Research $1980 \mathbf{4 0}$ 3768-3771.

32 Louiset E, Contesse V, Groussin L, Cartier D, Duparc C, Perraudin V, Bertherat J \& Lefebvre H. Expression of vasopressin receptors in ACTH-independent macronodular bilateral adrenal hyperplasia causing Cushing's syndrome: molecular, immunohistochemical and pharmacological correlates. Journal of Endocrinology 2008 $1961-9$.
33 de Herder WW \& Lamberts SW. Is there a role for somatostatin and its analogs in Cushing's syndrome? Metabolism $1996 \mathbf{4 5}$ $83-85$.

34 Lebrethon MC, Avallet O, Reznik Y, Archambeaud F, Combes J, Usdin TB, Narboni G, Mahoudeau J \& Saez JM. Food-dependent Cushing's syndrome: characterization and functional role of gastric inhibitory polypeptide receptor in the adrenals of three patients. Journal of Clinical Endocrinology and Metabolism $1998 \mathbf{8 3}$ 4514-4519.

35 Unger N, Serdiuk I, Sheu SY, Walz MK, Schulz S, Schmid KW, Mann K \& Petersenn S. Immunohistochemical determination of somatostatin receptor subtypes $1,2 \mathrm{~A}, 3,4$, and 5 in various adrenal tumors. Endocrine Research 200430 931-934.

36 Willenberg HS, Stratakis CA, Marx C, Ehrhart-Bornstein M, Chrousos GP \& Bornstein SR. Aberrant interleukin-1 receptors in a cortisol-secreting adrenal adenoma causing Cushing's syndrome. New England Journal of Medicine 1998339 27-31.

Received 5 April 2010

Accepted 7 April 2010 